\title{
Optimalisasi Peran Guru PAI Ideal dalam Pembelajaran Fiqh di Masa Pandemi Covid-19
}

\author{
Firman Mansir*, Halim Purnomo \\ Universitas Muhammadiyah Yogyakarta, Indonesia*, Universitas Muhammadiyah \\ Yogyakarta, Indonesia \\ *Jl. Brawijaya, Geblagan, Tamantirto, Kec. Kasihan, Yogyakarta, Daerah Istimewa \\ Yogyakarta 55183 \\ *Email: firmanmansir@umy.ac.id
}

\begin{abstract}
This study aims to analyze the roles and strategies of teachers in learning fiqh during the current pandemic. The learning productivity of ordinary Islamic education teachers on the effectiveness of using learning strategies. In fiqh learning has a separate style, so Islamic education teachers must really be able to determine the appropriate and effective models and strategies. In addition, the learning patterns that are currently being applied are not perfectly effective, it can lead to creativity or strategies that can be applied during learning. At present, many learning systems are carried out virtually or online, which have a positive impact on learning, but on the other hand also have a negative impact, due to several factors that hinder the learning process virtually. Thus, this decision is based on the ideal conditions of PAI teacher optimization in the application of fiqh learning, especially in the current pandemic era with productive and effective actualization of learning.
\end{abstract}

Keywords: Islamic Education Teacher, Fiqh Learning, Covid-19

Abstrak: Penulisan ini bertujuan menganalisis peran dan strategi guru dalam pembelajaran fiqh pada masa pandemi saat ini. Produktifitas pembelajaran guru PAI biasa dipengaruhi pada efektivitas penggunaan strategi belajar. Pada pembelajaran fiqh memiliki corak tersendiri, sehingga guru PAI harus benar-benar dapat menentukan model dan strategi yang tepat dan efektif. Selain itu, pola efektivitas belajar yang diterapkan saat ini belum sepenuhnya efektif, bisa disebabkan kurangnya kreativitas atau strategi yang mempuni untuk diterapkan saat pembelajaran. Saat pandemi saat ini, banyak sistem pembelajaran yang dilakukan secara virtual atau online, yang memiliki berdampak positif untuk berlangsungnya pembelajaran, namun di lain sisi juga memiliki dampak negatif, disebabkan karena beberapa faktor yang menghambat proses pembelajaran secara virtual tersebut. Maka, penulisan ini bermaksud untuk mengetahui bentuk optimalisasi guru PAI yang ideal dalam penerapan pembelajaran fiqh khususnya di masa pandemi saat ini dengan aktualisasi pembelajaran secara produktif dan efektif.

Kata Kunci: Guru Pendidikan Islam, Pembelajaran Fiqh, Covid-19

Jurnal Pendidikan Agama Islam Al-Thariqah Vol. 5, No. 2, Juli - Desember 2020

Received: 13 October 2020; Accepted 17 December 2020; Published 20 December 2020

*Corresponding Author: firmanmansir@umy.ac.id 


\section{PENDAHULUAN}

Pendidikan merupakan salah satu pondasi bangsa dalam membangun dan menciptakan generasi cendekiawan yang suatu saat menjadi generasi penerus perjuangan bangsa yang berkemajuan. Pembelajaran Fiqih yang merupakan salah satu sub Pendidikan Agama Islam (PAI ) dapat menjadi pondasi ruh dalam aspek pengetahuan (Khusna, 2016).

Maka sebelum mengenal lebih tentang aspek pembelajaran Fiqh, maka kita perlu mengetahui dahulu istilah dari pembelajaran dan Fiqh. Pembelajaran adalah suatu proses yang melibatkan seorang pendidik dan peserta didik untuk belajar. Sedangkan Fiqh adalah ilmu yang mempelajari tentang syariat Islam, pengertian lainnya dapat kita ambil pada Q.S At - Taubah ayat 122 , dalam ayat ini menjelaskan bahwa konteks Fiqh adalah memahami, mengetahui dan mendalami hukum dan syariat Islam (Imam Hanafi, 2012).

Dengan demikian dapat disimpulkan, pembelajaran Fiqh adalah suatu proses belajar yang mengarah pada cara pemahaman mengenai suatu hukum dan syariat Islam. Guru Fiqh merupakan seorang pendidik yang sedang melakukan proses belajar memahami dan mendalam ilmu agama berupa aturan-aturan atau syariat Islam (Amalia and Ibrahim, 2017). Pada kaitannya dalam pembelajaran Fiqh, guru dituntut supaya mampu melaksanakan kegiatan hukum dan kaidah Fiqh dengan baik dan dapat dipahami oleh peserta didik, dalam penyampaian materi Fiqh tentu perlu memperhatikan metode yang tepat (Shaifudin, 2019).

Selanjutnya, berkaitan dengan cara belajar di era modern, sudah menjadi hal yang mungkin dalam upaya pengembangan strategi pembelajaran yang diselaraskan dengan teknologi. Tidak dipungkiri lagi pada era teknologi digital saat ini kemajuan teknologi informasi sudah sangat pesat sebagai imbas penguasaan ilmu pengetahuan dan teknologi (IPTEK). Karena itu dapat dicontohkan Melalui sistem modul sangat dimungkinkan siswa lebih termotivasi untuk belajar. Selain itu modul memfasilitasi individual learning sehingga kemajuan siswa dapat dikontrol oleh siswa itu sendiri sesuai dengan kemampuannya (Mawarni, Sella and Ali Muhtadi, 2017). Dalam kondisi saat ini, guru dituntut untuk mampu menggunakan teknologi secara baik dan bijak, bahkan dituntut untuk dapat mengkolaborasikan pendidikan dengan teknologi.

Seperti halnya yang terjadi saat ini,wabah virus corona menimbulkan beberapa polemik dan peraturan baru terkait penggunaan teknologi informasi sebagai media dalam berlangsungnya pembelajaran secara virtual atau online. Pada konteks umumnya, selama ini guru lebih cenderung menggunakan model pembelajaran verbalistik yaitu dengan bentuk ceramah dan tanya jawab yang biasanya dilaksanakan didalam kelas. Kondisi ini memungkinkan timbul rasa kejenuhan pada siswa, sebagai imbas dari sikap monoton oleh guru. Kondisi kejenuha dapat berakibat tidak aktifnya komunikasi antara siswa dan guru yang pada akhirnya berakibat sulit tercapainya tujuan pembelajaran. Oleh karena itu, perlu langkah antisipasi dengan mencoba atau menggunakan metode alternatif yang lebih memahamkan (Amalia and Ibrahim, 2017).

Atas dasar pertimbangan kondisi inilah, pendidik dalam pembelajaran fiqih tertuntut harus terus bergerak dinamis dengan tetap memperhatikan asas ketepatan dan keefektifitasan dalam penyampaian materi pembelajaran. Sehingga tercipta suasana komunikatif dalam pembelajaran yang dapat memungkinkan terbentuknya siswa yang berkualitas dan mampu menghadapi perkembangan zaman (Siswadi, 2016). Maka dengan upaya pembelajaran secara 
online di masa pandemi virus corona saat ini menjadi jelur efektif dalam usaha penyelenggaraan pendidikan. Disisi lain, terdapat beberapa faktor yang menjadi penghambat pelaksanaan pembelajaran tersebut, namun disisi lain juga memiliki dampak yang cukup efektif dalam mencapai tujuan pendidikan (Nur Ainiyah, 2013).

\section{KONSEP TEORI}

Menurut (Purnomo, halim, et al, 2020) bahwa proses implementasi online class management tetap mampu menjaga nilai-nilai karakter siswa di SMA Muhammadiyah 7 Yogyakarta. Pandangan di atas menguatkan jika pembelajaran online class mampu mempertahankan nilai-nilai pembelajaran dan berlangsung secara normal. Sementara itu menurut (Mansir, Firman and Halim Purnomo, 2020) memperkuat pernyataan di atas bahwa pembelajaran PAI dengan berbagai dinamika yang ada mampu tetap lebih mudah dalam belajar dengan berbagai kondisi yang ada, baik di dalam kelas maupun di tempat lainnya.

Hal ini pula diperkuat oleh penelitian (Mansir, Firman, Halim dan Tumin, 2020) bahwa penerapan pembelajaran PAI yang berbasis sains dan budaya dapat tetap mengutamakan nilainilai keislaman dalam proses pembelajaran di kelas, walaupun dalam kondisi yang terbatas.

Peran pendidikan agama khususnya pendidikan agama Islam sangatlah strategis dalam mewujudkan pembelajaran fiqh yang menyenangkan. Pendidikan agama merupakan sarana transformasi pengetahuan dalam aspek keagamaan (aspek kognitif), sebagai sarana transformasi norma serta nilai moral untuk membentuk sikap (aspek afektif), yang berperan dalam mengendalikan perilaku (aspek psikomotorik) sehingga tercipta kepribadian manusia seutuhnya.

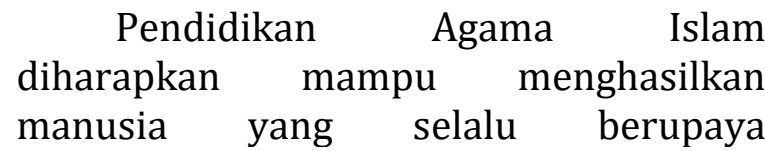
menyempurnakan iman, takwa, dan berakhlak mulia, akhlak mulia mencakup etika, budi pekerti, atau moral sebagai perwujudan dari pendidikan. Manusia seperti itu diharapkan tangguh dalam menghadapi tantangan, hambatan, dan perubahan yang muncul dalam pergaulan masyarakat baik dalam lingkup lokal, nasional, regional maupun global.

Mata pelajaran fiqh secara khusus adalah mengkaji suatu permasalahan hukum yang mengatur tentang aspekaspek kehidupan manusia, baik individu, masyarakat, ataupun hubungan manusia dengan Tuhan. Mata pelajaran fiqh yang ada disekolah dan madrasah memiliki perbedaan dalam bentuk pemberian pembelajaranya, dimana pelajaran fiqh di madrasah lebih banyak jika dibangdingkan dengan sekolah. Karena madrasah adalah lembaga instiusi keagamaan sedangkan sekolah adalah institusi umum yang mendapatkan pelajaran umum lebih banyak. Fiqh adalah undang-undang dalam beraktivitas sehari-hari yang memuat perintah, larangan, tatacara beribadah, sampai hukuman bagi pelanggarpelanggarnya. Sedangkan dalam menjalankan aktivitas beragama, umat islam menerapkan fiqh sebagai panduannya, seperti Tata cara bersuci, Shalat, Zakat, Haji, Iinfaq, Shadaqah, dan lain-lain yang telah diatur di dalamnya (Shaifudin 2019).

\section{METODE PENELITIAN}

Dalam penulisan ini, penulis menggunakan metode kualitatif. Penelitian ini menggunakan data kajian Pustaka dan data lapangan yang diperoleh secara observasi selama pandemi covid-19. Penulis terlebih dahulu mengumpukan hasil data yang ada dengan melalui analisis studi pustaka dan analisis studi lapangan. Studi kajian data 
tersebut digunakan supaya lebih menguatkan konkriditas bukti secara otentik yang diajukan secara rasional dengan teori hukum yang dapat menolong penguatan hipotesis yang ada.

\section{HASIL DAN PEMBAHASAN}

Pada umumnya peran dan kedudukan guru merupakansebagai motivator dan moderator dalam kegiatan pembelajaran. Dalam hal ini guru mempunyai andil dalam mengembangkan peserta didik dalam aspek pengetahuan, baik softskill maupun hardskill pada peserta didik. Dalam pandangan pendidikan peran orangtua yang lebih utama mendidik anakterutama dalam pengamalan ilmu agama. Maka peranguru di lingkungan sekolah juga mendidik dan membentuk karakter anak dalam aspek umum pendidikan yaitu membentuk jiwa serta akhlak dari peserta didik (Nurlindah, Mustamin, 2020).

Dalam UU SISDIKNAS Nomor 20 Tahun 2003 pasal 39 ayat 2, yang termaktub dalam UU dan pasal tersebut menjelaskan tentang sistem pendidikan nasional dan pendidik. Bab 1 dalam pasal 1 ayat 6 pada UUSPN Nomor 20 Tahun 2003 menjelaskan bahwasanya guru atau tenaga pendidik merupakan seseorang yang senantiasa membagikan ilmu pengetahuannya kepada peserta didik. Dapat diketahui bahwasanya profesi guru mempunyai peran yang sangat penting yakni sebagai pengajar.

Peran seorang guru PAI yang sangat penting sehingga pengembangan profesi guru harus di tingkatkan melalui keterampilan dapat diperoleh melalui proses pembelajaran. Pengembangan profesional guru dipelajari dan disajikan dalam sastra relevan di banyak berbeda cara. Tapi satu hal yang harus dipahami inti dari upaya tersebut adalah memahami bahwa pengembangan profesional adalah tentang guru belajar, belajar cara belajar, dan mengubah pengetahuan mereka praktek untuk kepentingan siswa mereka. Pada prinsipnya, dapat dikatakan bahwa tujuan utama dari pendidikan, secara umum, pencapaian persiapan optimal profesional masa depan (Amalia and Ibrahim, 2017).

Proses belajar mengajar dapat dikatakan sukses atau berhasil apabila guru mampu mengendalikan proses pembelajaran dengan baik. Hal ini karena guru merupakan suatu ujung tombak dalam proses pembelajaran. Dalam konteks peranan guru yang di harapkan yaitu meliputi; (a) Guru sebagai sumber belajar, (b) Guru sebagai fasilitator, (c) Guru sebagai pengelola pembelajaran, (d) Guru sebagai demonstrator, (e) Guru sebagai pembimbing, (f) Guru sebagai motivator, (g) Guru sebagai evaluator.

Namun pada kurikulum 2013 ini guru hanya sebagai fasilitator dan pengelola dalam pembelajaran, pembimbing, dan evaluator (Hikmat Kamal, 2018). Dalam cangkupan kurikulum ini, lebih mengajarkan siswa untuk mandiri dalam mencari dan mengembangkan ilmu pengetahuan, dan guru hanya melengkapi apabila peserta didik memerlukan tambahan seperti pemahaman dan pengetahua lainnya. Pada era ini kemajuan suatu teknologi mampu menjadi sumber belajar bagi peserta didik (Saleh, 2013).

Tugas guru dalam pandangan tokoh agama yakni Imam Al - Ghazali adalah menyempurnakan, membersihakan, mensucikan serta mengajak untuk mendekatkan diri kepada Allah SWT. (Frimayanti, 2017). Dari hal ini karena pada dasarnya Pedidikan Agama Islamini memajukan manusia untuk dapat dan mampu mendekatkan diri kepada Allah SWT. Tugas pendidik dalam pendidikan dapat disimpulkan menjadi tiga bagian, yaitu; (1) Sebagai instruksional (pengajar), yang bertugas merencanakan program pengajaran dan melaksanakan program yang telah disusun serta mengakhiri dengan pelaksanaan 
penilaian setelah program dilakukan. (2) Sebagai edukator (pendidik), yang mengarahkan peserta didik pada tingkat kedewasaan dan berkepribadian kamil seiring dengan tujuan Allah SWT menciptakannya. (3) Sebagai managerial (pemimpin), yang memimpin, mengendalikan kepada diri sendiri, peserta didik dan masyarakat yang terkait, terhadap berbagai masalah yang menyangkut upaya pengarahan, pengawasan, pengorganisasian, pengontrolan dan partisipasi atas program pendidikan yang dilakukan.

\section{Metode Pembelajaran dan Strategi Pembelajaran di Masa Pandemi}

Dapat kita ketahui bahwasanya wabah Covid-19 menjadi penghalang dari suatu proses belajar mengajar secara normal atau seperti biasanya yakni tatap muka, hal ini dapat menimbulkan dampak pada proses seorang guru dalam menyampaikan ilmu pengetahuan. Peran guru saat pandemi ini hanya bisa sebagai moderator, pembimbing dan evaluator. Dengan demikian peran guru sebagai pengajar mulai tidak dapat berjalan dengan maksimal danmembutuhkan metode serta strategi yang tepat. Pemanfaatan kemajuan teknologi informasi dapat diterapkan sebagai alat perantara belajarantara guru dan peserta didik dalam proses pembelajaran (Susilo et. al., 2020).

Dalam upaya penerapan teknologi informasi dalam pembelajaran, maka perlu diketahui kekurangan pada strategi dan metode yang digunakan. Adapun kekurang tersebut sebagai berikut; (1) Kegiatan harus dilakukan secara daring atau online. (2) Berketergantungan oleh jaringan sinyal, sehingga menghambat dalam akses internet yang digunakan. (3) Tidak semua memeliki laptop atau gadget dengan kapasitas yang baik. (4) Banyaknya tugas yang diberikan sebagai pengganti materi pelajaran sehingga siswa merasa memperoleh beban dalam mengerjakannya. (5) Tidak efektif terutama bagi siswa SD yang belum terlalu paham akan teknologi,

\section{Strategi Pembelajaran Selama Pandemi Covid-19}

Stragegi pembelajaran yang digunakan dalam pembelajaran khususnya selama pademi covid-19 adalah; (1) Tugas diberikan setiap minggunya sesuai jadwal supaya tidak terlalu membebani siswa selama pengerjaan. (2) Dukungan orang tua sangat berperan penting dalam anakanaknya agar selalu semangat mengerjakan tugas ataupun belajar dirumah selama pandemi Covid 19. (3) Guru dapat memberikan motivasi setiap memulai pembelajaran kepada peserta didiknya. (4) Guru dapat memberikan akses pengiriman berupa E-learning. (5) Pengiriman tugas bisa menggunakan media sosial yang mudah diakses oleh para siswa.

Dalam implementasi penggunaan media informasi sebagai media pembelajaran, maka dapat menggunakan metode yang meliputi; (1) Metode konvensial/metode ceramah. (2) Metode Diskusi. (3) Metode demostrasi. (4) Metode ceramah plus (ceramah dan metode lainnya). (5) Metode Resitasi. (6) Metode percobaan.

Dalam kondisi pandemi ini, pemerintah mengelurakan hibuan diantaranya; (1) Jaga jarak (2) Dilarang berkrumunan. (3) Rajin menjaga kebersihan. (4) Menggunakan media sebagai akses berkomunikasi antarperseorangan.

Oleh sebab itu, guru harus pandai dalam memilih strategi. Seperti contoh konsep pembelajaran yang diterapkan oleh dosen-dosen Universitas Muhammadiyah Yogyakarta, khususnya pada Fakultas Agama Islam, Program Studi Pendidikan Agama Islam di masa pandemi dalam proses belajar mengajar. Mereka menggunakan metode belajar berupa diskusi yang dimana metode 
tersebut dilaksanakan di media pembelajaran Learning Agama Islam UMY (MyclassUMY). pada mata kuliah Qur'an Hadits di Madrasah dan Sekolah yang di dengan menggunakan metode diskusi yang dimana diselanggarakan di media social seperti whattApp (WA). Pada mata kuliah Media Pembelajaran PAI misalnya pada mata kuliah ini metode yang diterapkan yakni metode ceramah dan diskusi, Pembelajaran ini diselenggarakan di media social berupa Microsoft office dan Microsoft Teams. Pada mata kuliah Regulasi Pendidikan dan Keguruan, dengan menggunakan metode diskusi dan diselenggarakan di media aplikasi Zoom. Pada mata kuliah Aqidah Akhlaq di Madrasah dan Sekolah, pembelajaran ini menggunakan metode diskusi serta pembelajaran diselenggarakan di media sosia berupa Microsoft office dan Microsoft Teams. Pada mata kuliah Manajemen Kelas, pembelajaran ini menggunakan metode pengamatan video dan kemudian diresume dalam kegiatan pembelajaran ini di selenggarakan di media social seperti Learning Agama Islam UMY (My Class UMY).

Pada mata kuliah Fiqh di Madrasah dan Sekolah, dalam proses belajar mengajar mengunakan metode diskusi dan kegiatan belajar ini dilaksanakan di media sosial berupa aplikasi WhatsApp (WA) dan menggunakan Microsoft Teams. Pada mata kuliah Statistik Pendidikan yang pembelajarannya menggunakan metode ceramah dalam bentuk video dan dalam melaksanakan pembelajaran dilakukan di media Learning Agama Islam UMY (My Class UMY).

Maka melalui contoh yang sudah dijelaskan tersebut kita dapat menemukan strategi pembelajaran yang dapat diterapkan melalui media sosial pada saat proses belajar mengajar secara online yang berlangsung secara baik, lancer dan menggembirakan, karena pembelajaran online terasa offline. Namun demikian perlu kiranya menjadi pertimbangan bahwa dalam penerapan media sosial atau teknologi informasi sebagai media pembelajaran perlu adanya evaluasi sebagai perbaikan model dan strategi pembelajaran yang akan diterapkan kedepannya.

\section{Bentuk Implementasi Belajar Secara Online}

Salah satu contoh bentuk implementasi belajar online dalam poin ini diambil melalui hasil analisis studi lapangan yaitu di SD Negeri Trirenggo 1 Bantul. Sebagaimana strategi yang sudah di jelaskan diatas, dalam penyampain materi ini tentu tidak hanya menggunakan metode saja, namun memperhatikan gaya belajar dari perserta didik termasuk dalam strategi pembelajaran. Gaya pelajar peserta meliputi: Pertama, Visual yaitu gaya belajar peserta didik yang lebih berdominan panca indra pengelihatan. Kedua, Auditori yaitu gaya belajar yang erdominan mengarah pada indra pendengaran. Ketiga, Kinestetik yaitu gaya belajar yang melibatkan gerak tubuh. Keempat, Global yaitu kemampuan dapat memahami sesuatu secra banyak atau keseluruhan. Kelima, Analitik yaitu kemampuan berupa melihat sesuatu mampu ditelaah secara spesifik dan terperinci.

Dengan mengetahui gaya belajar yang dimiliki peserta didik dapat memudahkan guru dalam menyampaikan suatu materi. Pada kondisi Covid-19 yang masih berlangsung, seorang guru dapat melakukan pembelajaran secara online dengan memperhatikan metode yang digunakan, seperti metode diskusi dan ceramah dapat kiranya dapat diterapkan melalui media daring. Selanjutnya, dalam contoh penerapan belajar daring dapat dilihat dari hasil wawancara penulis dengan guru PAI di SD Negeri Trirenggo Bantul, dimana dalam penerapan proses belajar dilakukan secara daring atau online sebagaimana yang dianjurakan oleh pemerintah. Serta pembelajaran 
dalam sekolah ini mengadakan kerjasama antara guru dengan wali murid untuk proses belajar mengajaran. Dalam kondisi yang masih dilanda wabah penyakit Covid-19 sekolah ini menggunakan metode Mastery Learning dalam pembelajarannya.

Adapun strategi pembelajaran yang diterapkan sebagai berikut:

Pertama, Guru pengampu mata pelajaran dengan membuat grup kelas online di whatsapp (WA). Ketentuan group kelas ini adalah; (a) Grup kelas online untuk kelas 1 - 4 anggota grup terdiri dari guru dan wali murid, hal ini karena rata - rata siswa belum memakai Hp dan akan lenih efektifnya jika grup hanya terdiri dari guru dan wali murid. (b) Grup kelas online untuk kelas 5 dan 6 terdapat 2 , grup pertama anggota grup terdiri dari guru dan murid, sedangkan grup ke dua anggota terdiri dari guru dan walimurid. Grup pertama digunakan untuk proses belajar mengajar, untuk grup kedua dingumtakan untuk kerjasama guru dan walimurid dalam memantau peserta didik.

Kedua, Guru memuat video inovatif dan sesuai dengan materi yang akan di sampaikan, kemudian video tersebut dikirim melalui semua grup yang ditampu. Isi video berupa penjabaran materi, untuk penugasaan dalam bentuk google from sehingga peserta didik tinggal mengisi pertanyaan-pertanyaan yang sudah ada dalam forum. Disetiap materi terdapat ujian kompetensi dimana ujian kompetensi ini digunakan untuk menggantikan ujian semesteran. Ujian kompetensi ini berupa menjawab pertanyan dalam bentuk pilihan ganda pada googler from yang sudah dibuat dan tugas praktit yang ditulis dalam bentuk Microsoft Word yang berkaitan dengan materi yang kemudan peserta mempratikan dan menvideokan praktik tersebut,hasil video praktik dikirim di via Grup whatsapp (WA).
Dengan demikian, pembelajaran adalah suatu proses yang melibatkan seorang pendidik dan peserta didik untuk belajar. Sedangkan Fiqh adalah ilmu yang mempelajari tentang syariat Islam, pengertian lainnya dapat kita ambil pada Q.S at-Taubah ayat 122 dalam ayat ini menjelaskan bahwasanya Fiqh adalah memahami, mengetahui dan mendalami syariat Islam. Dengan demikian dapat disimpulkan, pembelajaran Fiqh adalah suatu proses belajar yang mengarah pada pemahaman suatu hukum dan syariat Islam. Guru Fiqh merupakan seorang pendidik yang sedang melakukan proses belajar memahami dan mendalami suatu ilmu agama berupa aturan-aturan atau syariat Islam (Shaifudin, 2019).

Dalam implementasi cara belajar penggunaan media informasi sebagai media pembelajaran, maka dapat menggunakan metode yang meliputi; (1) Metode konvensial/metode ceramah, (2) Metode Diskusi, (3) Metode demostrasi, (4) Metode ceramah plus (ceramah dan metode lainnya), (5) Metode Resitasi, (6) Metode percobaan.

Dalam kondisi yang masih dilanda wabah Covid-19 sekolah ini menggunakan metode Mastery Learning dalam metode cara pembelajaran. Walaupun dalam sisi lain juga terdapat kelemahan dan kelebihan dalam penerapannya. Maka bentuk strategi dan metode belajar perlu dikembangkan (Syah, 2020). Strategi pembelajaran dapat berupa sebagai berikut:

Pertama, Guru pengampu mata pelajaran membuat grup kelas online di whatsapp (WA). Ketentuannya adalah; (a) Grup kelas online untuk kelas $1-4$ anggota grup terdiri dari guru dan wali murid, hal ini karena rata - rata siswa belum memakai $\mathrm{Hp}$ dan akan lenih efektifnya jika grup hanya terdiri dari guru dan wali murid. (b) Grup kelas online untuk kelas 5 dan 6 terdapat 2, grup pertama anggota grup terdiri dari guru dan murid, sedangkan grup ke dua 
anggota terdiri dari guru dan walimurid. Grup pertama digunakan untuk proses belajar mengajar, untuk grup kedua dingumtakan untuk kerjasama guru dan wali murid dalam memantau siswa.

Kedua, Guru memuat video inovatif dan sesuai dengan materi yang akan di sampaikan, kemudian video tersebut dikirimke semua grup yang dia tampu. Isi video berupa penjabaran materi, untuk penugasaan dalam bentuk google from sehingga peserta didik tinggal mengisi pertanyaan- pertanyaan yang sudah ada dalam forum. Ujian kompetensi ini berupa menjawab pertanyan dalam bentuk pilihan ganda pada google from yang sudah dibuat dan tugas praktit yang ditulis dalam bentuk Microsoft Word yang berkaitan dengan materi yang kemudan peserta mempratikan dan menvideokan praktik tersebut, hasil video praktik dikirim di via Grup.

\section{PENUTUP}

Pembelajaran fiqh dimasa pandemi covid-19 merupakan bagian dari realitas kehidupan masyarakat. Pandemi covid-19 ini menuntut seorang guru PAI untuk mengeluarkan berbagai metode yang efektif. Perlu kreativitas para Guru PAI agar pembelajaran tetap berjalan dengan baik, lancer, dan menyenangkan. Karena itu kemudian, salah satu inovasi yang wajib digunakan oleh guru PAI di masa pandemic covid 19 ini adalah pembelajaran secara online atau daring. Hal ini memberikan respon dari bermacam-macam namun hasilnya banyak memberi manfaat bagi peserta didik dalam menjalani pembelajaran secara online.[]

\section{DAFTAR RUJUKAN}

Amalia, Ema, and Ibrahim Ibrahim. "Efektivitas Pembelajaran Fiqih Dengan Mengunakan Metode Demonstrasi Di Madrasah Ibtidaiyah Negeri Desa PenggageMuba." JIP: Jurnal Ilmiah PGMI 3.1
(2017): 98-107.

Frimayanti, Ade Imelda. "Implementasi Pendidikan Nilai Dalam Pendidikan Agama Islam." Al-Tadzkiyyah: Jurnal Pendidikan Islam 8.2 (2017): 22747.

Hikmat Kamal. "Kedudukan Dan Peran Guru Dalam Perspektif Pendidikan Islam." Rausyan Fikr 14.1 (2018): 19-29.

Imam Hanafi. "Orientasi Fikih Dalam Pendidikan." Al-Fikra, Ilmiah Keislaman 11.1 (2012): 16-35.

Khusna, Nidhaul. "Peran Guru Pendidikan Agama Islam Dalam Menumbuhkan Karakter Anti Korupsi." Mudarrisa: Jurnal Kajian Pendidikan Islam 8.2 (2016): 173.

Mansir, Firman, and Halim Purnomo. "Islamic Education Learning Strategies Based on Multiple Intelligences in Islamic School." Psikis: Jurnal Psikologi Islami 6.1 (2020): 48-57.

man, Halim Purnomo, and Tumin Tumin. "Penerapan Pembelajaran Pendidikan Agama Islam Berbasis Sains Budaya Lokal Di Sekolah Dan Madrasah." Tarbawy: Indonesian Journal of Islamic Education 7.1 (2020): 70-79.

Mawarni, Sella, and Ali Muhtadi. "Pengembangan digital book interaktif mata kuliah pengembangan multimedia pembelajaran interaktif untuk mahasiswa teknologi pendidikan." Jurnal Inovasi Teknologi Pendidikan 4.1 (2017): 84-96.

Ainiyah, Nur. "Pembentukan karakter melalui pendidikan agama Islam." Al-Ulum 13.1 (2013): 25-38.

Nurlindah, Muh. Khalifah Mustamin, Musdalifah. "Manajemen Pendidikan Dan Tenaga Kependidikan Dalam Meningkatkan Mutu Pendidikan." Jurnal Idaarah 4.1 (2020): 40-51. 
Purnomo, Halim, et al. "Pendidikan Karakter Islami Pada Online Class Management di SMA $\begin{array}{lll}\text { Muhammadiyah } \quad 7 & \text { Yogyakarta }\end{array}$ Selama Pandemi Covid-19." Jurnal Tarbiyatuna 11.1 (2020): 91-100.

Saleh, Marhamah. "Strategi Pembelajaran Fiqh Dengan Problem-Based Learning." Jurnal Ilmiah Didaktika 14.1 (2013): 190-220.

Shaifudin, Arif. "Fiqih Dalam Perspektif Filsafat Ilmu: Hakikat Dan Objek Ilmu Fiqih." Al-Manhaj: Jurnal Hukum dan Pranata Sosial Islam 1.2 (2019): 197-206.

Siswadi. "Implementasi Pembelajaran Fiqih Berbasis Life Skill di MI AlHasan Kec. Sumpiuh Kabupaten Banyumas." JPA 17.2 (2016): 25171.

Susilo, Adityo et al. "Coronavirus Disease 2019: Tinjauan Literatur Terkini." Jurnal Penyakit Dalam Indonesia 7.1 (2020): 45.

Syah, Rizqon H. "Dampak Covid-19 Pada Pendidikan di Indonesia: Sekolah, Keterampilan, dan Proses Pembelajaran." Salam: Jurnal Sosial dan Budaya Syar'i 7.5 (2020): 395402. 